\title{
KOMPARASI METODE DAYA DUKUNG AXIAL PADA TIANG PANCANG TUNGGAL (STUDI KASUS JETTY BARGE LOADING CONVEYOR, MEULABOH)
}

\section{COMPARISON OF AXIAL METHOD FOR BEARING CAPACITY OF SINGLE PILE FOUNDATION (CASE STUDY OF JETTY FOR BARGE LOADING CONVEYOR, MEULABOH)}

\author{
Mudzakkir Maulana Rachman ${ }^{1}$, Haryo Dwito Armono² dan Kriyo Sambodho \\ ${ }^{1}$ Magister Teknik Kelautan, Bidang Keahlian Teknik Manajemen Pantai, Fakultas Teknologi Kelautan, \\ Institut Teknologi Sepuluh Nopember, Kampus ITS Sukolilo, Surabaya, 60111, Indonesia \\ ${ }^{2}$ Institut Teknologi Sepuluh Nopember, Kampus ITS Sukolilo, Surabaya, 60111, Indonesia \\ e-mail: mudzakkir.maulana@gmail.com
}

Diterima tanggal: 4 Juni 2013, diterima setelah perbaikan: 30 Juli 2013, disetujui tanggal: 1 Agustus 2013

\begin{abstract}
ABSTRAK
Pondasi tiang pancang merupakan salah satu faktor penting dalam struktur bangunan pantai, salah satunya adalah dermaga. Sebelum melaksanakan tahap konstruksi, perlu diketahui daya dukung tiang pancang axial yang merupakan besaran beban yang akan diterima. Studi ini dilakukan dengan menghitung perbedaan kapasitas daya dukung tiang pancang dengan diameter $600 \mathrm{~mm}$ yang digunakan pada Proyek Jetty Barge Loading Conveyor di Meulaboh dengan memperbandingan metode persamaan Meyerhof (1956) dan regulasi yang tertuang dalam The Overseas Coastal Area Development Institute Of Japan, OCDI (2002). Hasil perbandingan ke dua metode tersebut diperoleh daya dukung pondasi tiang pancang dengan menggunakan Metode Meyerhof yang menghasilkan daya dukung seberat 139,17 ton dan Metode OCDI menghasilkan daya dukung seberat 125,55 ton. Hasil studi ini merekomendasikan penggunaan persamaan dari Metode OCDI (2002) dikarenakan daya dukung tiang pancang yang digunakan dihitung berdasar kondisi kritis dan berada di lokasi yang rawan.
\end{abstract}

Kata kunci: pondasi tiang pancang, metode, daya dukung

\section{ABSTRACT}

Pile foundation is one important factor in coastal structures, one of them is jetty. Before construction of jetty, contractor need to estimate axial bearing capacity as load of pile. This study is to know difference of bearing capacity for diameter of pile $600 \mathrm{~mm}$ under Project of Jetty Barge Loading Conveyor, Meulaboh with comparing Meyerhof (1956) formula and regulation of The Overseas Coastal Area Development Institute of Japan, OCDI (2002 ). The result of methodology comparison are Meyerhofformula has a bearing capacity 139.17 tons, while OCDI has a bearing capacity 125.55 tons. Finally, this study suggest to use OCDI Method because it was estimated for critical condition and vulnerable area.

Keyword: pile foundation, method, bearing capacity

Komparasi Metode Daya Dukung Axial pada Tiang Pancang Tunggal (Studi Kasus Jetty Barge Loading Conveyor, Meulaboh) 


\section{PENDAHULUAN}

Dermaga adalah suatu bangunan pelabuhan yang digunakan untuk merapat dan menambatkan kapal yang melakukan bongkar muat barang dan menaikturunkan penumpang. Bentuk dan dimensi dermaga tergantung pada jenis dan ukuran kapal yang bertambat pada dermaga tersebut. Dermaga harus direncanakan sedemikian rupa sehingga kapal dapat merapat dan bertambat serta melakukan kegiatan di pelabuhan dengan aman, cepat dan lancar (Triatmodjo, 2009).

Pada struktur jetty dermaga terdapat pondasi untuk menahan beban struktur yang setiap struktur diperlukan pondasi sebagai dasar bangunan yang stabil. Hal ini disebabkan pondasi sebagai dasar bangunan harus mampu memikul seluruh beban bangunan dan beban lainnya, untuk diteruskan sampai kelapisan tanah pada kedalaman tertentu. Pondasi sendiri dibagi menjadi pondasi dangkal dan pondasi dalam. Pondasi dalam dapat berupa pondasi tiang pancang.

Salah satu kelebihan dari pondasi tiang adalah kekuatan daya dukungnya yang ditentukan berdasarkan tahanan ujung (end bearing) dan pelekatan tiang dengan tanah (cleef), dengan demikian pondasi ini sangat sesuai digunakan pada tanah lunak atau sedang dimana lapisan tanah keras terletak cukup jauh dari permukaan tanah. Kekuatan daya dukungnya dapat didefinisikan sebagai integritas daya dukung tiang pancang, dimana integritas tersebut adalah performa dari pondasi tiang pancang tersebut mampu memikul beban yang bekerja pada struktur tersebut.

Metode tentang perhitungan daya dukung tiang pancang secara aksial telah diperkenalkan oleh Meyerhof (1956) dengan cara metode statik yang konvensional. Adapun regulasi (code) yang memberikan juga sebuah metode secara statik akan tetapi terdapat beberapa variabel yang berbeda diantara kedua metode tersebut. Metode tersebut diberikan oleh Technical standards and commentaries for port and harbour facilties in Japan (2002) atau biasa dikenal dengan The Overseas Coastal Area Development Institute Of Japan (OCDI).

Tujuan penelitian ini adalah untuk mengetahui perbedaan adanya daya dukung aksial serta menambah pemahaman tentang perbedaan konsep antara metode Meyerhof (1956) dan OCDI (2002). Sehingga dalam penerapan di lapangan dapat dapat ditentukan metode perhitungan tiang pancang yang sesuai sebelum konstruksi dilakukan. Batasan masalah yang dibatasi penelitian ini adalah sebagai berikut:

1. Daerah yang akan ditinjau hanya di daerah penelitian

2. Data lingkungan dan material sesuai dengan data yang tersedia.

3. Analisis tiang pancang aksial dan lateral dilakukan secara tiang pancang tunggal tanpa kemiringan (better) dengan bentuk silinder seperti pada Gambar 1.

4. Tidak memperhitungkan settlement dan defleksi

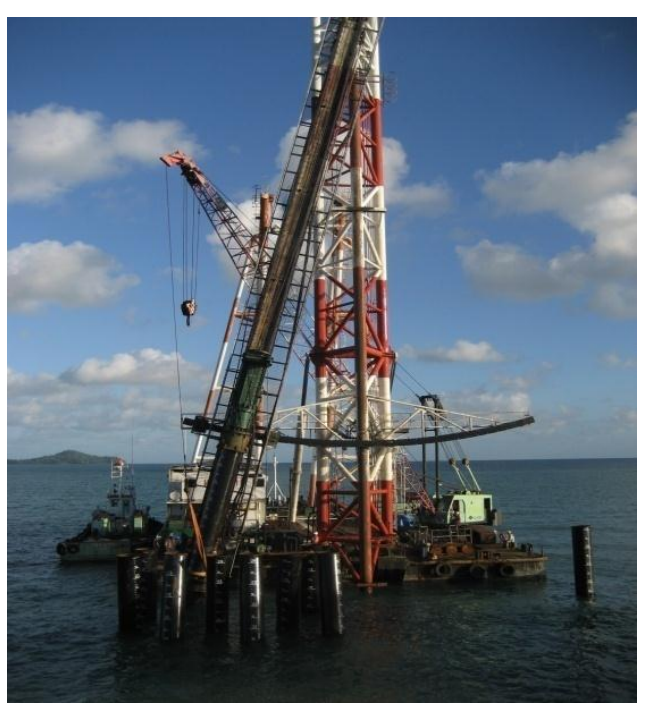

Gambar 1. Pondasi tiang pancang Figure 1.Pile foundation

Sumber : (Dwars, Heederik and Verhey, 2011)

Kapasitas daya dukung tiang metode Meyerhof (1956) merupakan jumlah dari kapasitas titik akhir atau perlawanan ujung dengan perlawanan selimut tiang, sebagaimana ditulis pada persamaan berikut.

$$
\mathrm{Q}=\mathrm{Qu}+\mathrm{Qf}
$$

dengan:

$\mathrm{Q} \quad=$ kapasitas daya dukung tiang

$\mathrm{Qu} \quad=$ kapasitas dukung pada ujung tiang

Qf = kapasitas daya dukung karena tahanan kulit 
Menurut Mayerhof (1956) kapasitas titik akhir atau ujung dapat dihitung dengan menggunakan persamaan:

Non kohesif: $\quad \mathrm{Qu}=40 \mathrm{~N} \times \mathrm{Ab}$

Kohesif: $\quad \mathrm{Qu}=4,5 \mathrm{~N} \times \mathrm{Ab}$

dimana:

$\mathrm{Qu} \quad=$ kapasitas daya dukung pada ujung tiang

$\mathrm{Ab} \quad=$ luas penampang tiang

$\mathrm{N} \quad=$ nilai SPT rata-rata

Sedangkan untuk menghitung tahanan kulit, tahanan selimut dapat diperoleh dari persamaan :

$$
\mathrm{Qf}=\mathrm{Fsi} \times \mathrm{As}
$$

dimana:

Qf = kapasitas tahanan kulit

As = luas selimut tiang

Fsi = daya lekatan tanah persatuan luas

$($ pasir $=\mathrm{N} / 5$ dan lempung $=\mathrm{N} / 2)$

The Overseas Coastal Area Development Institute of Japan (OCDI) atau Standar Teknis dan Komentar Fasilitas Pelabuhan di Jepang diterbitkan oleh Asosiasi pelabuhan Jepang, dan ditetapkan oleh Peraturan Menteri Perhubungan Jepang, yang didasarkan oleh penelitian-penelitian dari perguruan tinggi di Jepang, merupakan salah satu kaidah atau pedoman yang cukup banyak digunakan para insinyur khusunya Indonesia untuk mendesain pelabuhan. Di dalam salah satu bab dari panduan tersebut juga memberikan kajian tentang analisa perhitungan untuk daya dukung tiang pancang yang mengacu pada penelitian dari Kitajima et al. (1967).

Untuk tanah tak kohesif:

$\mathrm{Ru}=300 \mathrm{NAp}+2 \mathrm{As}$

dimana:

$\mathrm{Ru} \quad=$ daya dukung tiang $(\mathrm{kN})$

Ap = luas penampang pipa

As = luas selimut tiang yang terpenetrasi

$\mathrm{N} \quad=$ nilai SPT pada ujung tiang bawah

pondasi

$=$ nilai SPT rata-rata total
Dalam kajiannya, Technical Standarts and Commentaries For Port and Harbor Facilities In Japan memberikan formulasi dalam menghitung daya dukung tiang yaitu:

Untuk tanah kohesif:

$\mathrm{Ru}=8 \mathrm{Cp} \mathrm{Ap}+\mathrm{As}$

dimana:

$\mathrm{Cp} \quad=$ kohesi pada ujung tiang bawah

$=$ nilai adhesi rata-rata untuk total tiang terpenetrasi

Nilai adhesi (OCDI,2002) dapat diketahui dengan persamaan berikut:

$\mathrm{ca}=\mathrm{c} \quad: \mathrm{c} \leq 10$ ton $/ \mathrm{m}^{2}$

$\mathrm{ca}=10 \mathrm{ton} / \mathrm{m}^{2}: \mathrm{c}>10 \mathrm{ton} / \mathrm{m}^{2}$

Dalam Wesley (2012) juga disebutkan bahwa nilai kohesi dapat digunakan juga sebagai nilai dari kekuatan geser tanah tak teralirkan.

\section{BAHAN DAN METODE}

Adapun prosedur penelitian yang digunakan dalam penelitian ini yaitu:

\subsection{Lokasi Penelitian}

Lokasi penelitian berada di Gempong Peunaga, Kec. Meulaboh, Kab. Aceh Barat seperti yang tampak pada Gambar 2.

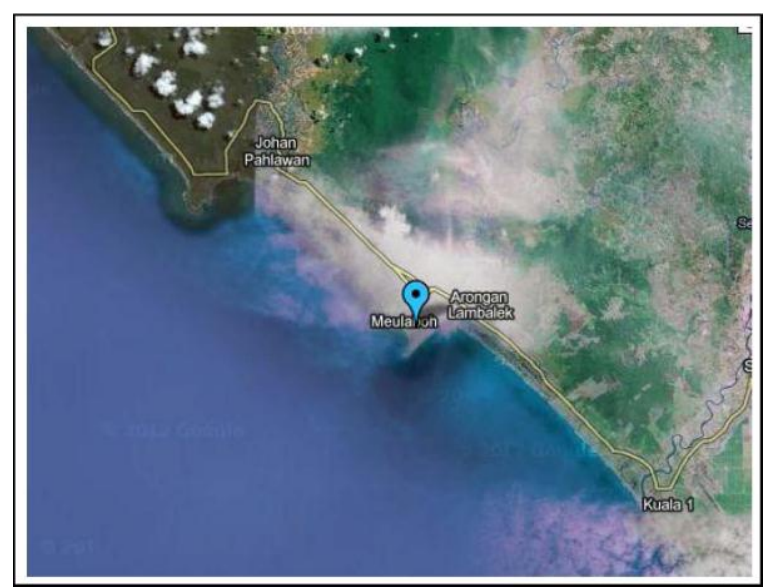

Gambar 2. Lokasi penelitian

Figure 2. Research location 


\subsection{Metode Pengambilan Data}

Dalam melakukan uji penetrasi lapangan digunakan metode pengujian penetrasi dengan SPT (SNI 03-4153-2008) yang dapat berlaku untuk tanah. Cara uji ini dimaksudkan sebagai pegangan dan acuan dalam uji penetrasi dengan SPT di lapangan pada benda uji tanah. Tujuannya adalah untuk memperoleh parameter perlawanan penetrasi lapisan tanah di lapangan dengan SPT, yang dapat dipergunakan untuk identifikasi perlapisan tanah yang merupakan bagian dari desain pondasi.

Uji SPT terdiri atas uji pemukulan tabung belah dinding tebal ke dalam tanah, disertai pengukuran jumlah pukulan untuk memasukkan tabung belah sedalam $300 \mathrm{~mm}$ vertikal. Dalam sistem beban jatuh ini digunakan palu dengan berat $63,5 \mathrm{~kg}$, yang dijatuhkan secara berulang dengan tinggi jatuh $0,76 \mathrm{~m}$. Pelaksanaan pengujian dibagi dalam tiga tahap, yaitu berturut-turut setebal $150 \mathrm{~mm}$ untuk masing-masing tahap.

Tahap pertama dicatat sebagai dudukan, sementara jumlah pukulan untuk memasukkan tahap ke-dua dan ke-tiga dijumlahkan untuk memperoleh nilai pukulan $\mathrm{N}$ atau perlawanan SPT (dinyatakan dalam pukulan/0,3 m). Ini adalah tes sederhana dan murah untuk memperkirakan kepadatan relatif tanah dan perkiraan parameter kekuatan geser. $\mathrm{N}$ value memberikan indikasi kepadatan relatif dari tanah bawah permukaan, dan digunakan dalam geoteknik korelasi empiris untuk memperkirakan kekuatan geser sifat tanah tersebut. SPT juga dapat digunakan dalam penentuan pendekatan nilai dari kekuatan geser tanah dapat juga digunakan untuk menentukan nilai dari sudut geser dalam pada tanah non kohesif. Mekanisme uji penetrasi lapangan dengan metode SPT seperti dalam Gambar 3.

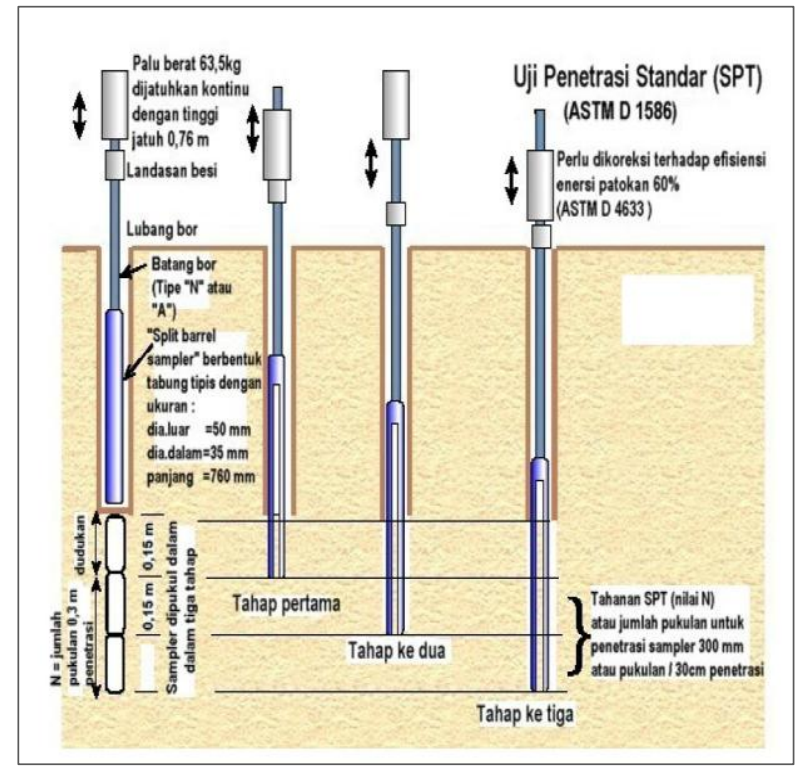

Gambar 3. Mekanisme SPT

Figure 3. SPT mechanism

Sumber : SNI 03-4153-2008

\section{HASIL DAN PEMBAHASAN}

\subsection{Data lapangan}

Data yang digunakan adalah dalam penelitian ini berupa data N-SPT dengan koordinat timur $\left(96^{\circ} 10^{\prime}\right.$ $\left.56,2^{\prime \prime}\right)$ barat $\left(04^{0} 06^{\prime} 09,0^{\prime \prime}\right)$ pengambilan data seperti dalam Gambar. 4.

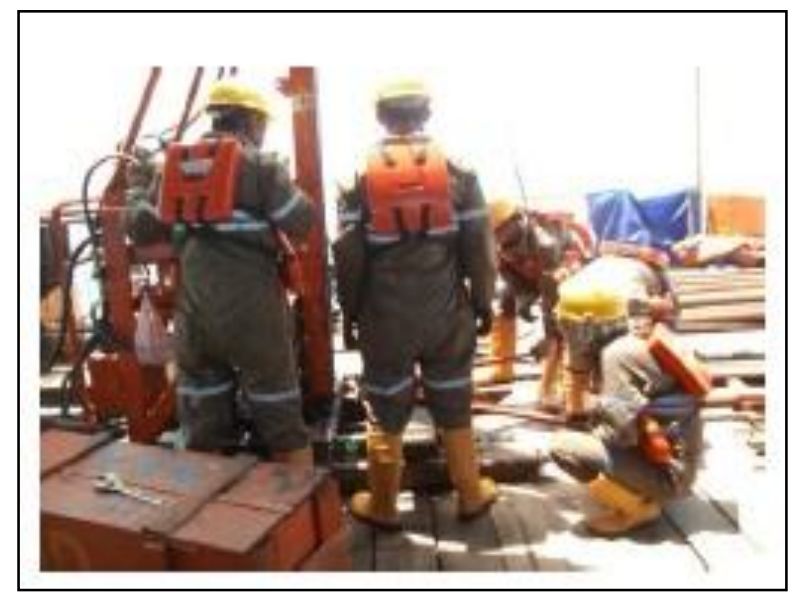

Gambar 4. Pelaksanaan pengambilan data SPT Figure 4. SPT data collection

Sumber : PT. Media Djaya Bersama (2012) 
Dari hasil pelaksanaan pengambilan data dengan tebal lapisan (layer) sebesar tiap 0,5 meter maka didapatkan pada kedalaman 0-3 meter di bawah permukaan, tanah diklasifikasikan kedalam tanah non-kohesif sedangkan sedangkan pada kedalaman 3,5 - 18 meter adalah lempung dengan plastisitas rendah sampai dengan sedang - lampung berpasir. Sedangkan 18,5 - 23,5 meter adalah pasir dengan gradasi buruk dan pasir berkerikil, sedikit atau sama sekali tidak mengandung butiran halus. Untuk kedalaman di bawah 23,5 - 24 merupakan tanah keras (hard coal) seperti yang terlihat pada Gambar 5.

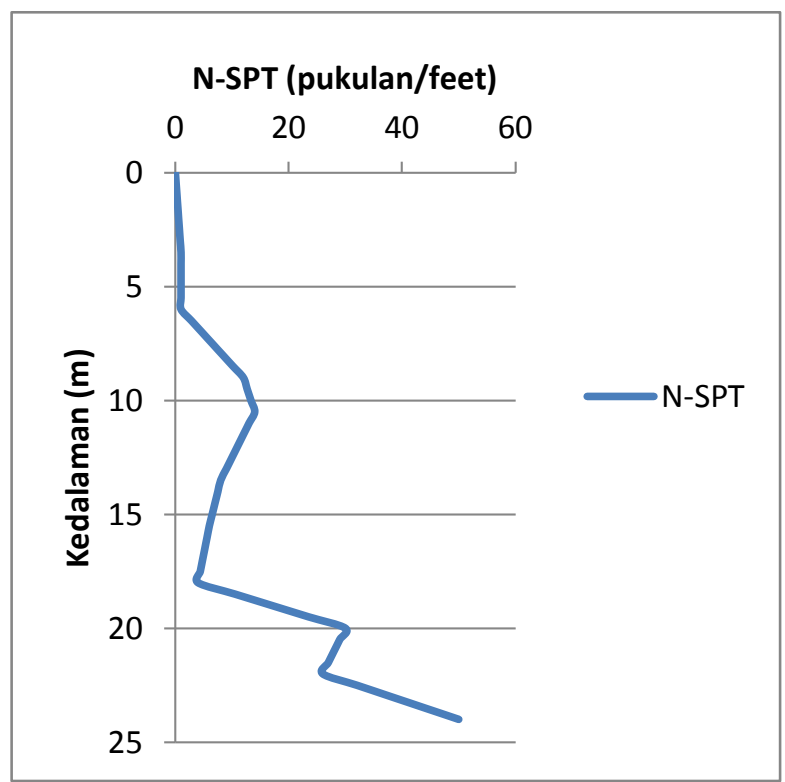

Gambar 5. Nilai N-SPT

Figure 5. N-SPT value

Salah satu parameter yang digunakan dalam penentuan nilai kapasitas daya dukung tiang pancang adalah sudut geser dalam untuk pasir dan tegangan geser tak teralirkan untuk tanah lempung. Pada tanah pasir pada kedalaman 0-1 meter didapatkan sudut geser dalam pasir sebesar $26,8^{\circ}$. Untuk kedalaman 1,5-2 meter sudut geser pasir $27,8^{\circ}$ dan untuk kedalaman 2,5-3 meter sudut geser pasir sebesar $29,2^{\circ}$.

Pada tanah lempung dengan kedalaman 3,5-5,5 meter mempunyai nilai tegangan tak teralirkan sebesar 1,25 ton $/ \mathrm{m}^{2}$. Sedangkan pada kedalaman 6-12 meter mempunyai besaran tegangan tak teralirkan 5 ton $/ \mathrm{m}^{2}$ dan pada kedalaman 12,5- 18 meter mempunyai nilai tegangan tak teralirkan sebesar 3 ton $/ \mathrm{m}^{2}$.

Sedangkan untuk tanah pada kedalaman 18,5 - 19 meter merupakan tanah pasir dengan sudut geser sebesar $24^{\circ}$. Kedalaman 19,5 - 20 meter besar sudut geser $27,8^{\circ}$ dan untuk 20,5 - 24 meter sudut geser dalam sebesar $25,8^{\circ}$.

Pada tanah di bawah permukaan air maka berat satuan tanah dihitung dengan menggunakan berat satuan efektif atau buoyant $\left(\gamma^{\prime}\right)$ yaitu berat satuan tanah jenuh dikurangi dengan satuan berat stuan air dalam hal ini sebesar 1 ton $/ \mathrm{m}^{3}$ (Bowless, 1997). Berat satuan pada setiap kedalaman yang digunakan dalam penelitian ini ditampilkan pada Gambar 6.

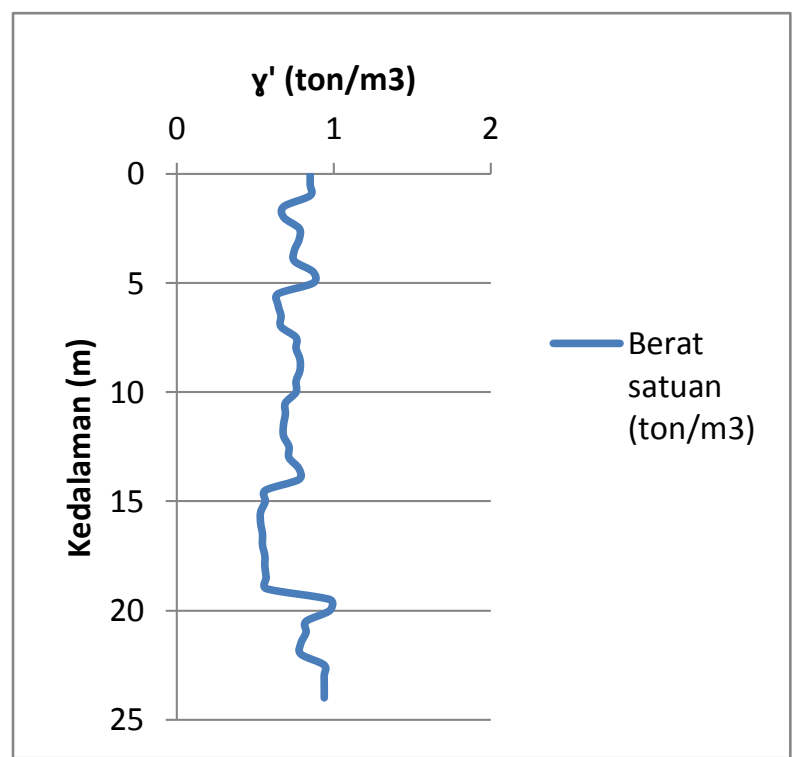

Gambar 6. Berat satuan tanah Figure 6. Soil density

\subsection{Analisis Daya Dukung Aksial}

Dari hasil analisa penentuan besaran daya dukung tanah secara aksial dengan diameter tiang pancang $600 \mathrm{~mm}$ didapatkan kurva perbandingan dua metode antara Meyerhof (1956) dengan OCDI (2002) seperti yang tampak pada Gambar 7. 


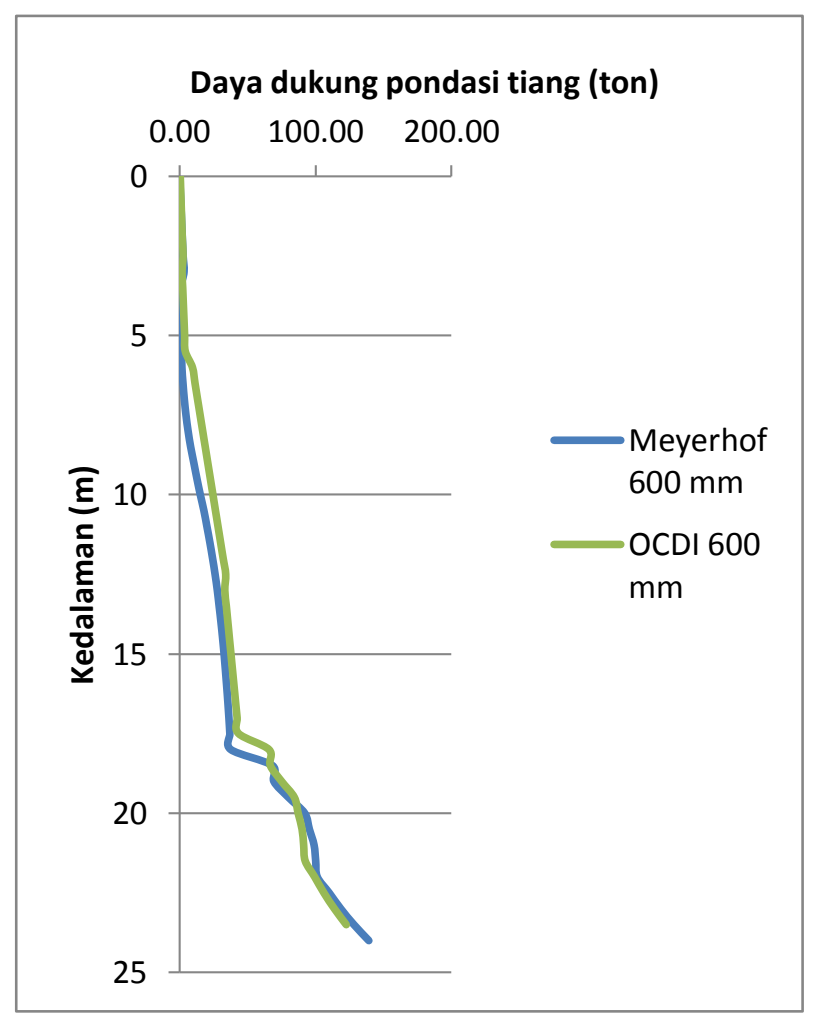

Gambar 7. Daya dukung aksial

Figure 7. Axial pile foundation bearing capacity

Dari hasil perhitungan pada Gambar 6. dengan menggunakan metode Meyerhof (1956) dan OCDI (2002) untuk daya dukung aksial didapatkan bahwa daya dukung tiang pancang dengan metode OCDI secara keseluruhan pada jenis tanah kohesif lebih besar dibandingkan dengan metode Meyerhof akan tetapi dengan jenis tanah non kohesif atau pasir metode Meyerhof mempunyai daya dukung lebih besar dimana dalam perhitungan tersebut menggunakan angka keamanan sebesar 2,5.

Untuk daya dukung aksial pada kedalaman 24 meter (rencana pemancangan) di bawah dasar laut dengan jenis tanah pasir metode Meyerhof (1956) menghasilkan besar daya dukung pondasi tiang sebesar 139,17 ton $(\phi 600 \mathrm{~mm})$, sedangkan untuk metode OCDI (2002) sebesar 125,55 Ton $(\phi 600 \mathrm{~mm})$ jika dilihat pada kedalaman yang sama yaitu 24 meter maka besar perbedaannya 16,62 ton atau $11,94 \%$.

Dalam Geotechnical Engineering Principles And Practice (Murthy, 2000) disebutkan bahwa metode Meyerhof (1956) dengan menggunakan nilai SPT pada tanah pasir mempunyai nilai daya dukung yang cukup konservatif (kecil) dibandingkan dengan metode lain seperti Coyle and Castello (1981). Namun dalam penelitian ini nilai daya dukung kapasitas tiang pancang dengan metode OCDI (2002) mempunyai nilai daya dukung yang lebih kecil dari Meyerhof (1956).

Pada prinsipnya dari kedua metode tersebut terdapat variabel yang berbeda dalam penggunaannya, variabel tersebut yang secara langsung digunakan sebagai masukan (input) pada persamaan yang digunakan yaitu tegangan geser tak teralirkan (undrained shear strength). Pada metode OCDI (2002) gaya geser sangat berperan dalam menentukan nilai daya dukung tiang pancang terutama pada tanah kohesif atau lempung, sedangkan untuk tanah metode Meyerhof (1956) persamaan yang dipakai tidak menggunakan undrained shear strength secara langsung sebagai nilai masukan.

Pada keadaaan tanah non kohesif atau pasir pola yang ditunjukkan hampir sama hanya besaran nilai daya dukungnya yang berbeda hal ini dikarenakan terdapat faktor konstanta yang berbeda. Seperti faktor pengali pada Meyerhof (1956) menggunakan nilai 40 sedangkan pada OCDI (2002) menggunakan nilai 300 akan tetapi harus dibagi dengan nilai percepatan gravitasi untuk menjadi satuan ton, untuk itu nilainya akan menjadi lebih rendah dari Meyerhof (1956).

Dalam penentuan metode daya dukung tiang pancang sesuai dengan Murthy (2000) dalam Geotechnical Engineering Principles And Practice dimana metode yang baik yang digunakan dalam penentuan kapasitas daya dukung tiang pancang yaitu metode dengan daya dukung terkecil atau terendah bila terdapat lebih dari satu metode yang digunakan karena dengan asumsi demikian maka kontruksi yang akan dibangun akan lebih diperkuat.

Perbedaan hasil dari kapasitas daya dukung tanah tiang pancang dapat dilihat seperti pada Tabel 1 dimana dalam tabel tersebut terdapat beberapa kriteria dan rekomendasi metode apa yang sebaiknya digunakan dalam penelitian ini. Rekomendasi pemilihan metode yang sesuai diberikan dengan asumsi daya dukung tiang pancang terendah (Murthy, 2000) agar konstruksi yang dibangun lebih diperkuat dan tetap 
memperhatikan jenis tanah kritis, dimana tanah kritis merupakan jenis tanah dengan daya dukung terendah pada masing-masing metode.

Tabel 1.Komparasi metode daya dukung tiang pancang

Table 1.Comparison pile foundation bearing capacity

\begin{tabular}{|c|c|c|}
\hline Kriteria & Meyerhof & OCDI \\
\hline $\begin{array}{l}\text { Kesesuaian } \\
\text { jenis tanah }\end{array}$ & $\begin{array}{l}\text { Semua jenis } \\
\text { tanah }\end{array}$ & Semua jenis tanah \\
\hline $\begin{array}{l}\text { Jenis Tanah } \\
\text { kritis }\end{array}$ & Kohesif & Non kohesif \\
\hline $\begin{array}{l}\text { Variabel } \\
\text { berpengaruh }\end{array}$ & $\begin{array}{ll}- & \text { N-SPT } \\
\text { - } & \text { Koefisien } \\
& \text { pengali } \\
\text { - } & \text { Lekatan } \\
& \text { selimut tiang } \\
\text { - } & \text { Berat satuan } \\
& \text { tanah }\end{array}$ & $\begin{array}{ll}- & \text { N-SPT } \\
- & \text { Koefisien } \\
& \text { pengali } \\
- & \text { Nilai } \\
& \text { tegangan } \\
\text { geser tak } \\
\text { teralirkan } \\
\text { - } \quad \text { Berat satuan } \\
\text { tanah }\end{array}$ \\
\hline
\end{tabular}

Rekomendasi Dilihat dari nilai besaran daya dukung tanah yang diperoleh dengan parameter angka keamanan yang sama maka direkomendasikan menggunakan metode OCDI untuk tanah kombinasi (kohesif dan non kohesif) serta pondasi bangunan yang berada pada lokasi yang rawan dan jangka waktu penggunaan struktur yang lama (umur) dengan asumsi daya dukung tiang pancang kritis.

Sumber : Meyerhof (1956), The Overseas Coastal Area Development Institute Of Japan (2002)

\section{KESIMPULAN DAN SARAN}

\section{Kesimpulan}

Setelah dilakukan perhitungan dan analisa data maka menjawab pertanyaan pada rumusan masalah sebelumya didapatkan kesimpulan bahwa:

1. Daya dukung tiang pancang aksial pada kedalaman 24 meter di bawah permukaan dasar laut dengan jenis tanah pasir serta diameter pondasi tiang pancang $(\phi) 600 \mathrm{~mm}$ metode Meyerhof yaitu sebesar 139,17 ton, sedangkan untuk metode OCDI sebesar 125,55 ton, untuk daya dukung aksial maka sesuai dengan Murthy (2000) dalam subjek penelitian ini direkomendasikan menggunakan metode OCDI (2002) dengan menggunakan asumsi Murthy (2000) bahwa metode daya dukung yang disarankan adalah metode dengan daya dukung terendah.

2. Pada jenis tanah kohesif maka disarankan untuk menggunakan metode meyerhof (1956) sedangkan pada jenis tanah non kohesif disarankan menggunakan metode OCDI (2002).

\section{Saran}

Yang dapat disarankan pada akhir penelitian ini adalah :

1. Untuk penelitian selanjutnya perlu diperhitungkan variasi diameter pondasi tiang pancang untuk mengetahui perbedaan besaran daya dukung jika mempunyai diameter yang berbeda.

2. Perlu dilakukan perhitungan daya dukung tiang pancang secara lateral.

\section{UCAPAN TERIMA KASIH}

Terima kasih penulis ditujukan untuk berbagai pihak yang telah membantu dalam penelitian :

1. Dr. Haryo D. A dan Dr. Kriyo S. atas bimbingan selama proses dan penulisan hasil penelitian.

2. Murdjito M.Sc. Eng atas kontribusi data yang dipergunakan selama penelitian.

\section{DAFTAR PUSTAKA}

Bowles, J. E. 1997. Foundation analysis and design. The McGraw-Hill Companies, Inc. Singapore.

Dwars, Heederik and Verhey. 2011. Feasibility study Meulaboh Port. Media Group.

Kitajima, S., S. Kakizaki, Y. Hanaki, and T. Tahara. 1967. On the axial bearing capacity of single piles, tech. Note of PHRI, No. 36.

Meyerhof, G. G. 1956. Penetration tests and bearing capacity of cohesionless soils. JSMFD, ASCE, Vo. 82, SMI. 
Murthy, V. N. S. 2000. Geotechnical engineering principles and practice of soil mechanic foundation enginering. American University. CRC Press.

PT. Media Djaya Bersama. 2012. Barge loading facility offshore geotechnical. PT. Trans Tek Engineering.

SNI 03- 4153. 2008. Cara uji penetrasi lapangan dengan SPT. Badan Standardisasi Nasional.

The Overseas Coastal Area Development Institute Of Japan (OCDI). 2002. Technical standarts and commentaries for port and harbor facilities in Japan. Japan: Daikousha Printing Co., Ltd.

Triatmodjo, B. 2009. Perencanaan pelabuhan. Yogyakarta: Beta Offset.

Wesley, D. W. 2012. Mekanika tanah untuk tanah endapan dan residu. Yogyakarta: Andi. 